\title{
381267
}

WSRC-RP-91-1215-TL

Keywords: HEME, Spray Nozzle, Spray Pattern

Retention: Permanent

January 6, 1992

D. B. Amerine

Westinghouse Savannah River Company

Attention:

J. F. Ortaldo, 704-S (5)

SRL

RFISRE ¿OPY

\section{DETERMINATION OF PROCESS CONDITIONS FOR THE DWPF MELTER OFF-GAS HEME SPRAY NOZZLE (U)}

DWPF-Technical asked SRL to determine operating conditions for the melter off-gas HEME spray nozzles, which have a capacity 3 to 4 times that specified in the Basic Data Report (BDR). Two operating ranges are specified in the attached report by L. M. Lee.

- $0.8-1.3 \mathrm{gph}$ water and $20-30 \mathrm{psig}$ air, which is at the low end of the recommended range for the current DWPF nozzles.

- $0.25-0.35 \mathrm{gph}$ water and $10-18 \mathrm{psig}$ air, which is consistent with the DWPF BDR.

The higher range is being recommended for Cold Chemical Runs to improve HEME flushing and minimize modifications. The higher water rate has the potential to increase the pressure drop across the HEME's to an unacceptable level. However, based on industrial experience this risk is judged to be minimal.

The SRL tests show that if lower water rates are required, the existing nozzles will produce an acceptable spray. However, modification of the water delivery systems to ensure accurate delivery at the lower rate is required.

Eid flotizakeiter

E. W. Holtzscheiter Manager, Defense Waste Processing Technology Savannah River Laboratory

CC: J. A. Gentilucci, 704-S H. H. Elder, 704-S

P. R. Burket, 704-27S

L. A. Patterson, 704-30S

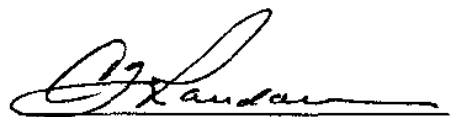

C. T. Randall

Authorized Derivative Classifier
J. T. Carter, 704-1T

L. F. Landon, 704-T

D. H. Miller, 704-T

J. R. Zamecnik, 704-1T

SRL Records (4) 
Westinghouse Savannah River Company

WSRC-RP-91-1215

Savannah River Laboratory

Keywords: HEME, HEPA, Spray Nozzle, Spray Pattern

Retention Period: Permanent

CC: E. W. Holtzscheiter, 773-A

J. E. Lunn, 704-T

R. E. Roaden, 704-T

J. T. Carter, 704-1T

L. F. Landon, 704-T

D. $\mathrm{H}$ Miller, 704-1T

A. S. Choi, 704-1T

J. R Zamecnik, 704-1T

PMC Flies

December 15, 1991

To: C. T. Randall, 704-T

From: L. Lee, 704-T Ree

\section{DETERMINATION OF PROCESS CONDITIONS FOR THE SPRAY NOZZLE FOR THE DWPE MELTER OFF-GAS HEME (U)}

\section{SUMMARY:}

Using an actual DWPF HEME spray nozzle, operating ranges of atomizing air pressure that will produce a continuous fine mist have been determined for two water flow rate ranges. At 0.8 to $1.3 \mathrm{GPH}$ water rate the atomizing air pressure at the nozzle should be from 20 to 30 psig. At 0.25 to $0.35 \mathrm{GPH}$ water rate the atomizing air pressure at the nozzle should be from 10 to 18 psig. Too low atomizing air pressure results in incomplete atomization while too high atomizing air pressure gives intermittent spray. When the HEME is clean the high water flow rate range will give a higher pressure drop across the HEME compared to the lower water flow rate. However, this pressure drop is expected to be acceptable, and the higher water

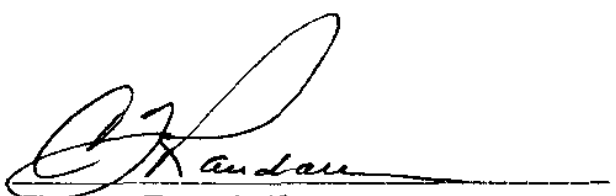

C. T. Randall, Authorized Derivative Classifier 
flow rate, which is recommended by the HEME vendor, may do a better job of flushing material from the HEME element. Furthermore, it is easier to implement the high water flow rate conditions in the DWPF. Therefore, the high water flow rate conditions are recommended for testing during cold chemical runs. Cold run data will determine whether minor modifications to the water delivery system to allow the lower water rate specified in the DWPF Basic Data Report (BDR) are required.

The spray nozzle supplied in the DWPF HEME is designed for water flow rates three to four times that specified in the BDR, which has been demonstrated in large scale testing at TNX. A major objective of this study was to determine if the nozzle could be operated effectively at the lower BDR specified flow rate. It was determined that efficient operation at the lower water rate is possible. However, the BDR specified air rate for that water rate is 10 to 20 times too low.

Increasing atomization air and water flow rate to the high rates recommended for cold runs should have no adverse impact on the DWPF because they are only about $1 \%$ of the melter off-gas and $0.34 \%$ of water recycled, respectively. The current BDR (1) atomizing air pressure and water flow rate should be changed to reflect the findings contained in this report.

The current pressure gage used to monitor air pressure and flow rate has a range of 25 to $75 \mathrm{psig}$, it should be changed to a range of 0 to $60 \mathrm{psig}$ to increase the operability and accuracy. The water rate must be controlled within the range 0.8 to $1.3 \mathrm{GPH}$ for the high rate case and $0.3+/-0.05 \mathrm{GPH}$ for the lower water rate case.

\section{INTRODUCTION:}

The DWPF melter off-gas systems have High Efficiency Mist Eliminators (HEME) upstream of the High Efficiency Particulates Air filters (HEPA) to remove fine mist and particulates from the off-gas. To have an acceptable filter life and an efficient HEME operation, air atomized water is sprayed into the melter off-gas and onto the HEME surface. The water spray keeps the HEME wet, which dissolves the soluble particulates and enhances the HEME efficiency.

DWPF Technical requested SRL to determine the conditions for the DWPF nozzle which will give complete atomization of water so 
that the HEME will operate efficiently. Since the air pressure and flow rate to generate the desired spray are not known before hand, an experiment was performed in two stages. The first stage involved preliminary tests which mapped out a general operating region for producing the desired spray pattern (2). Afterward, all the gages and meters were changed to suitable ranges for the conditions which generated an acceptable spray. This report summarizes the results and the conclusions of the second stage experiment.

\section{SPRAY NOZZLE AND FLOW DIAGRAM OF THE SPRAY NOZZLE TEST FACILITY:}

The spray nozzle uses air to atomize the water. The atomizing air and water enter the nozzle through separate ports. They meet inside the nozzle where the expanding air atomizes the water. To generate a very fine mist over a large area the mixture impinges on a horizontal section which helps create a wide angle spray. The nozzle tested was made by the Spraying System, Incorporated with the following ID (189-6-62-160 H. C. HC276). It has a rated capacity 3 to 4 times that specified in the BDR. The nozzle tested was supplied by DWPF Technical from one of the DWPF off-gas HEME units.

The water rate originally specified in the BDR was derived from a recommendation of the Du Pont Engineering Department of $50 \mathrm{mg}$ of water per cubic foot of off-gas. This water rate, which has proven satisfactory in tests on large scale HEME's at TNX, is the only water rate that has been tested by SRL.

The Spray Nozzle Facility is setup at the TNX tank farm. A flow diagram for the facility is given in Figure 1 . We have a pressure gage (G-1) to measure the air pressure in the rotameter. This gage is necessary because we need the rotameter reading and air pressure to determine the actual air flow rate. The pressure gage G-2 measures the air pressure which is available at the nozzle for atomizing the water. Water pressure at the nozzle is measured by pressure gage G-3. 


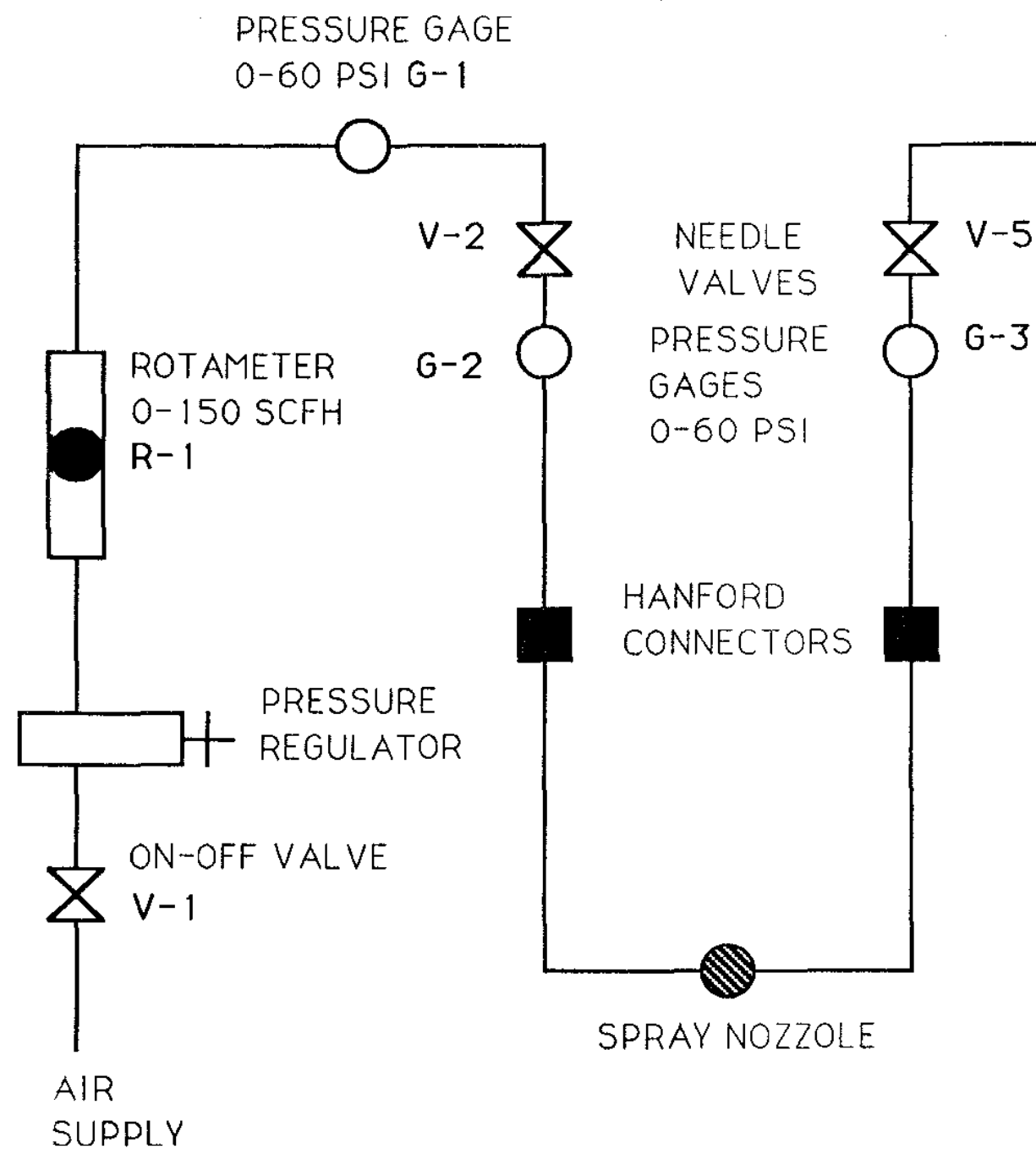

ROTAMETER $0-2 \mathrm{GPH}$ R-2

ON-OFF

VAL VE V-3

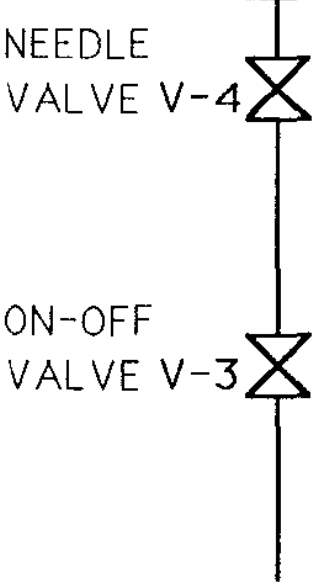

FILTERED

WATER

SUPPLY

FIGURE 1: FLOW DIAGRAM FOR NOZZOLE TESTING FACILITY 


\section{TEST RESULTS:}

The nozzle experiment was carried out when the ambient temperature was $54^{\circ} \mathrm{F}$. The water flow rate ranged from 0.3 to 1.3 gph and air pressure at the nozzle ranged from 10 to $35 \mathrm{psig}$. When the air pressure was too high and/or the water pressure was too low the air backed up into the water line and the atomization stopped. After a few seconds the water line pressure built up sufficiently to force water through; the result was intermittent atomization. Table 1 gives the experimental conditions which resulted in intermittent atomization. All data were readings from the rotameters and pressure gages except the actual air flow rates which are calculated based on the data obtained. See reference (2).

\section{TABLE 1: EXPERIMENTAL CONDITIONS RESULTING IN INTERMITTENT} VERY FINE SPRAY

\begin{tabular}{|c|c|c|c|c|c|}
\hline INDICATED & PRESSURE & PRESSURE & WATER FLOW & ACTUAL AIR & PRESSURE \\
\hline FLOW SCFH & PSIG & PSIG & RATE GPH & FLOW RATE & PSIG \\
\hline R-1 & G-1 & G-2 & $\mathrm{R}-2$ & SCFH & G-3 \\
\hline 80 & 60 & 20 & 0.3 & 183 & NA \\
\hline 110 & 60 & 30 & 0.3 & 251 & NA \\
\hline 110 & 60 & 30 & 0.5 & 251 & NA \\
\hline 105 & 60 & 28 & 0.5 & 240 & NA \\
\hline 120 & 60 & 35 & 1.3 & 274 & NA \\
\hline
\end{tabular}

The intermittent atomization was caused by too high air pressure and/or too low water flow rate. In order to produce a continuous very fine spray I reduced the air pressure and/or increased the water flow rate. The experiments following these changes produced a very fine and continuous spray, and the results are given in Table 2.

\section{CONCLUSIONS:}

Using an actual DWPF HEME spray nozzle operating ranges of atomizing air pressure that will produce a continuous fine mist have been determined for two water flow rate ranges. At 0.8 to $1.3 \mathrm{GPH}$ water rate the atomizing air pressure at the nozzle should be form 20 to 30 psig. At 0.25 to $0.35 \mathrm{GPH}$ water rate the atomizing air pressure at the nozzle should be from 10 to 18 psig. Too low atomizing air pressure results in incomplete atomization while too high atomizing 
air pressure gives intermittent spray. The high water flow rate range will give higher pressure drops across the HEME compared to lower water flow rate when the HEME is clean. However, the high water flow rate may do a better job of flushing material from the HEME element. Furthermore, it is easier to implement the high water flow rate conditions in the DWPF. Although, the high water flow rate conditions have not been tested in the Scale Glass Melter or IDMS off-gas system, they are being recommended for cold chemical runs based on the vendor's recommendation, impact minimization and the low risk involved.

\section{TABLE 2: EXPERIMENTAL CONDITIONS RESULTING IN VERY FINE CONTINUOUS SPRAY}

\begin{tabular}{|c|c|c|c|c|c|}
\hline $\begin{array}{l}\text { INDICATED } \\
\text { FLOW SCFH } \\
\text { R-1 }\end{array}$ & $\begin{array}{l}\text { PRESSURE } \\
\text { PSIG } \\
\text { G-1 }\end{array}$ & $\begin{array}{l}\text { PRESSURE } \\
\text { PSIG } \\
\text { G-2 }\end{array}$ & $\begin{array}{l}\text { WATER FLOW } \\
\text { RATE GPH } \\
\text { R-2 }\end{array}$ & $\begin{array}{l}\text { ACTUAL AIR } \\
\text { FLOW RATE } \\
\text { SCFH }\end{array}$ & $\begin{array}{l}\text { PRESSURE } \\
\text { PSIG } \\
\text { G-3 }\end{array}$ \\
\hline 80 & 60 & 20 & 0.8 & 183 & 4 \\
\hline 80 & 60 & 20 & 1.3 & 183 & 4.5 \\
\hline 110 & 60 & 30 & 1.3 & 251 & 6 \\
\hline 110 & 60 & 30 & 0.8 & 251 & 6 \\
\hline 93 & 60 & 25 & 1.0 & 212 & 5 \\
\hline 50 & 60 & 10 & 0.3 & 114 & 2 \\
\hline 55 & 60 & 12 & 0.3 & 125 & 2 \\
\hline 65 & 60 & 14 & 0.3 & 148 & 3 \\
\hline 70 & 60 & 16 & 0.3 & 160 & 3 \\
\hline 75 & 60 & 18 & 0.3 & 171 & 3 \\
\hline
\end{tabular}

Increasing atomization air and water flow rates to the high rates recommended for cold run should have no adverse impact on the DWPF because they are only about $1 \%$ of the melter off-gas and $0.34 \%$ of water recycled, respectively.

The current pressure gage used to monitor air pressure and flow rate has a range of 25 to $75 \mathrm{psig}$, it should be changed to a range of 0 to 60 psig to increase the operability and accuracy.

\section{REFERENCE:}

(1) Basic Data Report, Defence Waste Processing Facility, Sludge Plant 200-S Area, DPSP 80-1033 Volume 1 Part 20 Item 250 Revision 80.

(2) L. Lee to C. T. Randall "PRELIMINARY TEST OF THE SPRAY NOZZLE FOR THE DWPF HEME" SRL-PMC-91-0088, November 19, 1991. 